\title{
PENGARUH GENGGAM TANGAN TERHADAP TEKANAN DARAH PADA PENDERITA HIPERTENSI
}

\author{
Isnaini Rahmawati ${ }^{1}$, Dewi Suryandari ${ }^{2}$ \\ ${ }^{1,2)}$ Program Studi Keperawatan Program Sarjana \\ Universitas Kusuma Husada Surakarta \\ isnaini.rahmawati88@gmail.com
}

\begin{abstract}
ABSTRAK
Hipertensi merupakan salah satu penyakit yang tidak banyak diketahui orang sebelum memeriksakan tekanan darahnya. Hipertensi dapat menyebabkan kematian bila tidak diketahui serta tidak terkontrol sehingga disebut silent disease. Penanganan untuk penyakit hipertensi dapat dilakukan dengan dua cara, yaitu secara farmakologi dan nonfarmakologi. Penatalaksanaan farmakologi seringkali mengakibatkan beberapa efek samping, antara lain: kelelahan, sering kencing, dan jantung berdebar. Sekarang ini mulai banyak dikembangkan penatalaksanaan secara nonfarmakologi karena minim efek samping. Optimalisasi dalam kegiatan sehari-hari diprediksi dapat membantu menurunkan tekanan darah pada pasien hipertensi untuk mencegah terjadinya hipertensi emergensi. Berbagai kegiatan dapat dilakukan antara lain: senam ergonomis, konsumsi bahan makanan yang tinggi potassium, dan lain-lain. Genggam tangan diprediksi pula dapat membantu mengontrol tekanan darah. Penelitian ini bertujuan untuk mengetahui pengaruh genggam tangan terhadap tekanan darah pada penderita hipertensi. Metode yang digunakan dalam penelitian ini adalah Metode Quasi-Experiment dan analisis data menggunakan Uji Wilcoxon. Intervensi yang dilakukan adalah berupa tindakan mandiri melakukan genggam tanggan selama lima belas menit, empat kali dalam satu hari, selama empat belas hari. Alat penelitian yang dipakai yaitu sphygnomanometer untuk mengukur tekanan darah. Hasil analisis diperoleh hasil p-value $0,000(\mathrm{p}<0,05)$ pada tekanan darah sistolik dan diastolik, sehingga ada pengaruh terapi genggam tangan terhadap tekanan darah pada penderita hipertensi.
\end{abstract}

Kata kunci : genggam tangan, hipertensi, tekanan darah

\begin{abstract}
Hypertension is a disease that not many people know before checking their blood pressure and can cause death if it is not known and controlled, so it is called the silent disease. Treatment for hypertension can be carried out in 2 types, namely pharmacologically and non-pharmacologically. Pharmacological management often results in several side effects, including fatigue, frequent urination and heart palpitations. Currently, many non-pharmacological treatments are being develope because of the minimum side effects. Optimalization in daily activities is predicted to help lower blood pressure in hypertensive patients to prevent hypertensive emergencies. Various activities can be done, including ergonomic exercise, consumption of foods high in potassium, and the others. It also predicted that holding hands can help control blood pressure. This study aims to determine the effect of holding hands on blood pressure in patients with hypertension. The method used in this research is quasi-experimental and data analysis using the Wilcoxon test. The intervention carried out was in the form of independent action to hold hands for 15 minutes, four times in 1 day, for 14 days. The research tool used was a sphygmomanometer to measure blood pressure. The analysis results obtained $p$ value $0.000(p<0.05)$ on systolic and diastolic blood pressure, so there is an effect of handheld therapy on blood pressure in hypertensive patients.
\end{abstract}

Keywords: hold hands, hypertension, blood pressure 


\section{PENDAHULUAN}

Tekanan darah tinggi atau biasa disebut dengan hipertensi merupakan suatu permasalahan kesehatan yang sering kali ditemukan pada masyarakat di dunia, termasuk Indonesia. Seseorang dikatakan mempunyai penyakit hipertensi apabila terjadi kenaikan tekanan darah sistolik >140 mmHg dan tekanan darah diastolik > $90 \mathrm{mmHg}$. Tekanan darah yang tinggi, seringkali terjadi tanpa muncul gejala yang berarti, namun dapat menimbulkan komplikasi. Hipertensi merupakan salah satu faktor risiko dalam terjadinya penyakit jantung coroner(Ramandityo, 2016).Hipertensi merupakan penyebab terbesar dari kejadian strok(Cheever, 2014).

American Heart Association (AHA) mengatakan bahwa penderita hipertensi di Amerika adalah 75,5 juta jiwa, namun 90-95\% kasus tidak diketahui penyebabnya (Kementerian Kesehatan et al., 2019). Ardiyansyah (2012) menyatakan bahwa perkiraan kenaikan kasus tekanan darah tinggi pada negara berkembang pada tahun 2025 adalah $80 \%$ dari jumlah kasus 639 juta kasus pada tahun 2000. Jumlah ini akan meningkat 1,15 milyar kasus pada tahun tersebut.

Data dari hasil riset kesehatan dasar tahun 2018 (Kementrian Kesehatan, 2018) didapatkan persentase kejadian penderita hipertensi adalah sebesar 34,1 \% yang meningkat dari data sebelumnya yaitu $25,8 \%$. Jawa Tengah adalah satu dari beberapa provinsi yang mempunyai kejadian hipertensi yang lebih tinggi dari angka nasional.

Salah satu provinsi yang mempunyai prevalensi tekanan darah tinggi lebih tinggi dari pada tahun 2012 adalah Jawa Tengah. Angka kasus tertinggi pada kelompok penyakit jantung dan pembuluh darah adalah hipertensi esensial/ primer (Kementerian Kesehatan, 2019). Hal ini menjadi sesuatu yang perlu diteliti lebih lanjut karena merupakan hal yang penting untuk segera ditindaklanjuti dan ditangani dengan baik.
Usia yang paling banyak diderita oleh penderita hipertensi adalah usia lanjut. Menurut (Kholifah, 2016) seseorang dikatakan usia lanjut adalah seseorang yang telah mencapai usia 60 tahun keatas. Hal ini sejalan dengan penemuan dari WHO yang menunjukkan bahwa kejadian hipertensi akan meningkat sejalan dengan bertambahnya usia, yakni 1/10 orang berusia 2030 tahunan dan $1 / 5$ orang berusia 50 tahunan. Satu per tiga orang dewasa di dunia memiliki penyakit hipertensi (WHO, 2013).

Permasalahan pada penderita hipertensi yang paling sering terjadi adalah terkait dengan kepatuhan dalam konsumsi obat. Banyak dari penderita hipertensi yang menolak untuk rutin minum obat hipertensi dalam waktu yang lama karena khawatir akan komplikasi/ efek samping yang ditimbulkan dari obat yang dikomsunsi. Efek samping dari obat hipertensi yang dirasakan pasien adalah jantung berdebar, mulut kering, batuk dll (Dennison-himmelfarb et al., 2014)

Terapi farmakologi dan nonfarmakologi dilakukan dengan tujuan utama yaitu pencegahan terhadap kejadian hipertensi emergensi.Terapi non farmakologis yang dapat dilakukan kepada pasien meliputi: pengaturan makan, olahraga, dan pengelolaan stres. Salah satu teknik untuk mengelola stres adalah dengan teknik relaksasi. Teknik ini dilakukan dengan cara melatih otototot supaya rileks (Sulistyarini, 2013). Terapi relaksasi efektif untuk menurunkan tingkat depresi, kecemasan, dan stres (Bahrami, 2012).

Terapi relaksasi dapat dilakukan dengan banyak cara, antara lain genggam jari dan genggam tangan. Genggam jari dapat menurunkan Mean Arterial Pressure (MAP) pada pasien hipertensi (Taufik, 2018). Genggam jari dapat menurunkan tekanan darah pada pasien hipertensi (Diana et al., 2016). Kedua peneliti tersebut melakukan penelitian terkait dengan genggam jari. Adapun genggam jari yang dimaksud adalah menggenggam jemari satu persatu, dari jempol 
menuju ke kelingking secara bergantian dengan menggunakan tangan yang berlawanan, sehingga terasa denyut nadi dari genggaman tersebut. Sejauh ini belum ada penelitian tentang genggam tangan untuk mengontrol hipertensi, namun beberapa artikel menuliskan terkait dengan manfaat ilmiah dari genggam tangan yaitu ketika ada tekanan dalam sentuhan, detak jantung akan turun, dan tekanan darah akan turun. Perbedaan penelitian sebelumnya dengan penelitian ini adalah pada penelitian sebelumnya genggam jari satu persatu dari jempol menuju ke kelingking, sedangkan pada penelitian ini berupa genggam tangan dengan jari-jari tangan kanan dan kiri saling terkait dan diberikan sedikit tekanan sehingga terasa denyut dari dari sela-sela jari secara bersamaan.

Hasil dari studi pendahuluan atau analisis lapangan ditemukan bahwa kejadian penyakit terbanyak adalah hipertensi. Berdasarkan hasil wawancara dengan ketua posyandu didapatkan bahwa hanya pemberian obat-obatan yang diberikan oleh dokter untuk pasien yang mengalami hipertensi dengan tekanan darah sistolik diatas $160 \mathrm{mmHg}$, sedangkan di bawah itu tidak diberikan obat. Tidak ada tindakan nonmedis yang dilakukan, sehingga peneliti tertarik untuk melakukan penelitian terkait dengan pengaruh genggam tangan terhadap tekanan darah pada penderita hipertensi di posyandu tersebut.

\section{METODOLOGI}

Penelitian ini menggunakan jenis penelitian kuantitatif, dengan Metode Quasi Experiment dengan One Group Pretest-Posttest Design without Control. Populasi yang digunakan pada penelitian ini adalah semua lansia di Posyandu Menur 2, Windan, Makamhaji, Kartasura, Sukoharjo, Jawa Tengah dengan total 83 lansia.

Kriteria inklusi dalam penelitian ini sebagai berikut.

1. Lansia yang tekanan darahnya lebih dari 140/90 mmHg (baik yang konsumsi atau tidak mengonsumsi obat hipertensi).

2. Lansia yang mampu melakukan genggam tangan (tidak ada gangguan ekstremitas).

3. Lansia yang bersedia menjadi responden penelitian.

Sampel yang terlibat dalam penelitian ini adalah 31 responden. Proses pengambilan data dalam penelitian ini terdiri dari pretest yang berupa pengukuran tekanan darah awal, kemudian dilanjutkan dengan intervensi mandiri berupa genggam tangan empat kali sehari $(+15$ menit) selama empat belas hari. Selanjutnya posttest berupa pengukuran tekanan darah akhir.

Pengukuran tekanan darah menggunakan spygmomanometer digital yang sudah terkalibrasi.

\section{HASIL}

Tabel. 1. Distribusi Karakteristik Berdasarkan Jenis Kelamin

\begin{tabular}{lcc}
\hline \multicolumn{1}{c}{ Jenis Kelamin } & n & \% \\
\hline Laki-laki & 6 & 19,3 \\
Perempuan & 25 & 80,7 \\
\hline Total & 31 & 100 \\
\hline
\end{tabular}

Berdasarkan tabel 1 dapat disimpulkan bahwa jenis kelamin responden paling banyak yaitu perempuan sejumlah 25 responden (80,7\%).

Tabel 2. Distribusi Karakteristik Berdasarkan Usia

\begin{tabular}{llll}
\hline Variabel & Min & Max & Mean \\
\hline Usia & 60 & 79 & 65,48 \\
\hline
\end{tabular}

Berdasarkan tabel 2 dapat disimpulkan bahwa usia minimal responden adalah 60 tahun, maksimal 79 tahun, dan rerata usia responden adalah 65,48 tahun. 
Tabel 3. Tekanan Darah Sebelum Terapi Genggam Tangan

\begin{tabular}{lrrr}
\hline $\begin{array}{l}\text { Tekanan } \\
\text { Darah }\end{array}$ & Mean & Median & $\begin{array}{c}\text { Std. } \\
\text { Deviasi }\end{array}$ \\
\hline Sistole & 153,77 & 149,00 & 12,883 \\
Diastole & 96,42 & 94,00 & 6,652 \\
\hline
\end{tabular}

Berdasarkan tabel 3 dapat digambarkan bahwa rerata tekanan darah sistole sebelum terapi genggam tangan adalah 153,77 $\mathrm{mmHg}$ dengan standar deviasi 12,883. Sedangkan tekanan darah diastolik nya adalah $96,42 \mathrm{mmHg}$ dengan standar deviasi 6,652.

Tabel 4. Tekanan Darah Setelah Terapi Genggam Tangan

\begin{tabular}{lrrr}
\hline $\begin{array}{l}\text { Tekanan } \\
\text { Darah }\end{array}$ & Mean & Median & $\begin{array}{c}\text { Std. } \\
\text { Deviasi }\end{array}$ \\
\hline Sistole & 148,19 & 145,00 & 11,1591 \\
Diastole & 93,61 & 90,00 & 5,457 \\
\hline
\end{tabular}

Berdasarkan tabel 4 dapat digambarkan bahwa rerata tekanan darah setelah terapi genggam tangan adalah 148,19 mmHg dengan standar deviasi 11,1591, sedangkan tekanan darah diastolik adalah 93,61 $\mathrm{mmHg}$ dengan standar deviasi 5,457.

Tabel 5. Pengaruh GenggamTangan Terhadap Tekanan Darah

\begin{tabular}{llrr}
\hline $\begin{array}{l}\text { Tekanan } \\
\text { Darah }\end{array}$ & Fase & Mean & $\begin{array}{c}\text { Nilai } \\
\text { Signifikan }\end{array}$ \\
\hline Sistolik & Pre Test & 153,77 & 0,000 \\
& Post Test & 96,42 & \\
\multirow{2}{*}{ Diastolik } & Pre Test & 148,19 & 0,000 \\
& Post Test & 93,61 & \\
\hline
\end{tabular}

Berdasarkan tabel 5 Hasil uji SPSS dengan Uji Wilcoxon diperoleh $p$ value 0,000 pada tekanan darah sistolik dan 0,000 pada tekanan darah diastolik, dimana $\mathrm{p}<0,05$ maka Ho ditolak dan $\mathrm{Ha}$ diterima atau ada pengaruh genggam tangan terhadap tekanan darah lansia dengan hipertensi.

\section{PEMBAHASAN}

Berdasarkan hasil penelitian ini didapatkan bahwa sebagian besar responden adalah perempuan sebanyak 25 responden (80,7\%). Penelitian ini sejalan dengan penelitian yang dilakukan oleh (Kurniawan, 2019) yang menunjukkan bahwa dari responden terbanyak yaitu perempuan sebanyak 25 responden $(55,6$ $\%$ ). Begitu pula dengan penelitian dari Rahmawati dan Suryandari (2019) yang menyatakan bahwa $74 \%$ responden yang mengalami hipertensi adalah perempuan. Kusumawaty et al., (2016) menemukan data bahwa ada hubungan yang signifikan antara jenis kelamin dengan kejadian penyakit hipertensi pada lansia.

Wanita yang belum mengalami menopause akan dilindungi oleh hormon estrogen yang berperan dalam meningkatkan kadar High Density Lipoprotein (HDL) yang berfungsi sebagai sarana perpindahan kolesterol dari arteri dan jaringan ke liver untuk didaur ulang sehingga arteri menjadi bersih. Kadar kolesterol HDL rendah dan tingginya kolesterol LDL (Low Density Lipoprotein) akan memengaruhi proses terjadinya aterosklerosis dan mengakibatkan tekanan darah tinggi (Novitaningtyas, 2014). Hal ini sesuai dengan yang disampaikan oleh (Kumar V., Abul K.A., 2014) yang menjelaskan bahwa wanita yang belum mengalami menopause terhindar dari penyakit kardiovaskuler karena dilindungi oleh hormon estrogen yang dapat mencegah terjadinya aterosklerosis. Pada wanita pre menopasue, wanita mulai untuk kehilangan jumlah hormon estrogen yang melindungi dari kerusakan, penurunan jumlah hormon estrogen terjadi secara bertahap seiring dengan bertambahnya usia yang umurmnya terjadi pada usia 45 -55 tahun.

Wanita mengalami penurunan estrogen akan mengakibatkan peningkatan 
pelepasan enzim renin sehingga dapat memicu meningkatnya tekanan darah (Smantummkul, 2014).

Berdasarkan analisis peneliti, mayoritas responden dalam penelitian adalah perempuan pada fase menopause. Pada perempuan yang sudah menopause kadar estrogen akan berkurang yang mengkibatkan penyempitan pembuluh darah akibat kadar HDL berkurang sehingga terjadi penyempitan pembuluh darah yang meningkatkan tekanan darah.

Hasil penelitian berdasarkan nilai ratarata tekanan darah sistolik sebelum diberikan intervensi sebesar $153,77 \mathrm{mmHg}$ dan rata-rata tekanan darah diastolik $96,42 \mathrm{mmHg}$.

Responden terbanyak adalah lansia, peningkatan usia pada lansia akan menyebabkan resistensi dari pembuluh darah perifer dan aktivitas simpatik serta menurunnya sensitivitas refleks baroreseptor sehingga tekanan darah cenderung meningkat. Meningkatnya tekanan darah pada lanjut usia umumnya terjadi akibat dari menurunnya fungsi organ pada cardiovascular system yang ditandai dengan penebalan dan kekakuan katup jantung, sehingga akan terjadi penurunan elastisitas dari aorta dan arteri besar lainnya (Cheever, 2014).

Umumnya, tekanan darah dipengaruhi oleh kecepatan denyut jantung, volume sekuncup dan Total Peripheral Resistance (TPR). Oleh karena itu, apabila terdapat peningkatan dari salah satu diantaranya maka dapat menyebabkan hipertensi.

Perubahan struktur dan fungsi dalam sitem pembuluh darah perifer yang menjadi dasar dalam perubahan tekanan darah yang terjadi pada lanjut usia. Perubahan tersebut meliputi munculnya aterosklerosis, penurunan proses vasokonstriksi dan relaksasi otot polos pembuluh darah, dan hilangnya elsastisitas jaringan ikat akan menurunkan kemampuan distensi dan daya regang pembuluh darah.Akibatnya aorta dan arteri besar mengalami penurunan kemampuan dalam mengakomodasi volume darah yang dipompa oleh jantung (volume sekuncup), mengakibatkan penurunan curah jantung dan peningkatan tahanan perifer (Cheever, 2014).

Berdasarkan hasil penelitian dan teori yang terkait maka dapat disimpulkan peningkatan tekanan darah pada lansia umumnya terjadi akibat penurunan fungsi organ, perubahan anatomi dan fisiologis dari sistem pembuluh darah dan jantung. Apabila tidak dilakukan intervensi apapun untuk mengontrol tekanan darah, pasti akan ada kenaikan tekanan darah.

Hasil penelitian berdasarkan nilai ratarata tekanan darah sistolik setelah diberikan intervensi sebesar $148,19 \mathrm{mmHg}$ dan rata-rata tekanan darah diastolik 93,61 mmHg. Tekanan darah sistolik terjadi penurunan sebesar 5,58 $\mathrm{mmHg}$ dan tekanan darah diastolik mengalami penurunan sebesar 2,81 mmHg.

Berdasarkan hasil uji statistik didapatkan nilai signifikansi 0,000 pada tekanan darah sistolik dan 0,000 pada tekanan darah diastolik, sehingga dapat diambil kesimpulan terdapat pengaruh terapi genggam tangan terhadap tekanan darah lansia.

Pasien dengan tekanan darah tinggi membutuhkan pengelolaan tekanan darah untuk menjaga tekanan darah supaya tetap stabil (Syamsudin, 2011). Teknik genggam tangan merupakan teknik relaksasi yang dapat memberikan rasa nyaman, rileks dan tanpa efek samping (Sulistyarini, 2013)(Anwar, 2013) (Yuliastuti, 2015).

Dalam kondisi yang rileks empat kali dalam satu hari selama empat belas hari dapat meningkatkan aktivitas saraf parasimpatis dan menurunkan saraf simpatis sehingga dapat menurunkan kontraksi jantung dan denyut jantung.

Begitu pula ukuran pembuluh darah, mengalami vasodilatasi atau pelebaran diameter 
pembuluh darah sehingga terjadinya penurunan tekanan darah dengan menurunkan preload dan mengurangi afterload(Sulistyarini, 2013).

\section{SIMPULAN DAN SARAN}

Hasil Uji statistik dengan Uji Wilcoxon, nilai $p$-value 0,000 pada tekanan darah sistolik dan diastolik sehingga dapat disimpulkan ada pengaruh genggam tangan terhadap tekanan darah pada lansia dengan hipertensi

Saran dari penelitian ini adalah penderita hipertensi dapat melakukan tindakan mandiri genggam tangan ini untuk mengontrol tekanan darah sehingga dapat meminimalkan kejadian kematian akibat hipertensi emergensi.

\section{DAFTAR PUSTAKA}

Anwar, M. A. dan M. C. (2013). Efek Relaksasi Terhadap Penurunan Tekanan Darah Pada Penderita Hipertensi. Jurnal Ilmu Kesehatan, 2(1), 74-82.

Ardiyansyah. (2012). Medikal Bedah untuk Mahasiswa. Diva Press.

Bahrami;, F. K. S. B. M. M. V. (2012). The effects of relaxation on reducing depression, anxiety and stress in women who underwent mastectomy for breast cancer. Iran J Nurs Midwifery Res, 17(1), 30-33.

Cheever, S. C. S. B. G. B. J. L. Hinkle; K. H. (2014). Texk Book of Medical Surgical Nursing (12th ed.). Lippincot Williams and Wilkins.

Dennison-himmelfarb, C., Handler, J., \& Lackland, D. T. (2014). 2014 EvidenceBased Guideline for the Management of High Blood Pressure in Adults Report From the Panel Members Appointed to the Eighth Joint National Committee (JNC 8). 1097(5), 507-520. https://doi. org/10.1001/jama.2013.284427

Diana, R., Sari, K. (2016). Pengaruh Teknik Relaksasi Genggam Jari Terhadap
Penurunan Kecemasan Pada Pasien Pre Operasi Sectio Caesarea. Universitas Muhammadiyah Surakarta

Kesehatan, Kementerian, Hipertensi, R. I., \& Senyap, S. P. (2019). is n e tr Hipe.

Kesehatan, Kementrian. (2018). No Title. Kholifah, S. N. (2016). Keperawatan Gerontik.

Kumar V., Abul K.A., J. C. . (2014). Robbins and Cotran Pathologic Basic of Disease 9th Edition. Elsevier.

Kurniawan, I. ; S. (2019). Hubungan Olahraga, Stress dan Pola Makan dengan Tingkat Hipertensi di Posyandu Lansia di Kelurahan Sudirejo I Kecamatan Medan Kota. JHSP, 1(1), 10-17.

Kusumawaty, J., Hidayat, N., \& Ginanjar, E. (2016). Hubungan Jenis Kelamin dengan Intensitas Hipertensi pada Lansia di Wilayah Factors Related Events Sex with Hypertension in Elderly Work Area Health District Lakbok Ciamis. 16(2), 46-51.

Novitaningtyas, T. (2014). Hubungan Karakteristik (Umur, Jenis Kelamin, Tingkat Pendidikan) Dan Aktivitas Fisik Dengan Tekanan Darah Pada Lansia Di Kelurahan Makamhaji Kecamatan Kartasura Kabupaten Sukoharjo. Universitas Muhammadiyah Surakarta.

Organization, W. H. (2013). A global brief on Hyper tension World Health Day 2013.

Rahmawati, I ; Suryandari, D. (2019). Pengaruh

Sari Kacang Hijau Terhadap Tekanan Darah Pada Penderita Hipertensi Di Panti Wreda Dharma Bhakti Kasih Surakarta. Proceedings of the First Kusuma Husada International Nursing Conference : Kusuma Husada Surakarta School of Health Scince : 10.

Ramandityo, D. F. (2016). Hubungan Hipertensi Dengan Keparahan Penyakit Jantung Koroner Berdasarkan Sullivan Vessel 
Score. UIN Syarif Hidayatullah.

Smantummkul, C. (2014). Tingkat Kepatuhan Penggunaan Obat Antihipertensi Pada Pasien Hipertensi Di Instalasi Rawat Jalan Rsud Dr. Moewardi Pada Tahun 2014. Universitas Muhammadiyah Surakarta.

Sulistyarini, I. (2013). Terapi Relaksasi untuk Menurunkan Tekanan Darah dan Meningkatkan Kualitas Hidup Penderita Hipertensi. 40(1), 28-38.

Syamsudin. (2011). Buku Ajar Farmakoterapi

Kardiovaskuler dan Renal. Salemba
Medika.

Taufik, A. S. U. A. (2018). Pengaruh Relaksasi Genggam Jari Dan Nafas Dalam Terhadap Mean Arterial Pressure Pasien Hipertensi Primer. November, 76-85.

Yuliastuti, C. (2015). Effect Of Handheld Finger Relaxation On Reduction Of Pain Intensity In Patients With PostAppendectomy At Inpatient Ward, Rsud Sidoarjo. 5(3), 53-54. 
